\title{
Powdered Crystalline Silicotitanate (CST) Isotherms for SRS
} \section{Wastes}

by

R. A. Jacobs

Westinghouse Savannah River Company

Savannah River Site

Aiken, South Carolina 29808

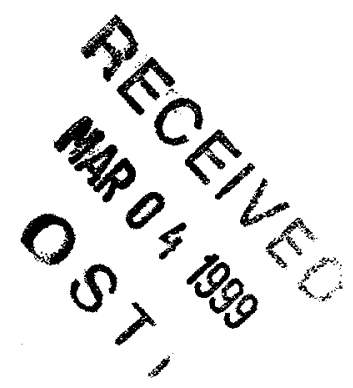

This paper was prepared in connection with work done under the above contract number with the U.S. Department of Energy. By acceptance of this paper, the publisher and/or recipient acknowledges the U. S. Government's right to retain a nonexclusive, royalty-free license in and to any copyright covering this paper, along with the right to reproduce and to authorize others to reproduce all or part of the copyrighted paper. 


\section{DISCLAIMER}

This report was prepared as an account of work sponsored by an agency of the United States Government. Neither the United States Government nor any agency thereof, nor any of their employees, makes any warranty, express or implied, or assumes any legal liability or responsibility for the accuracy, completeness, or usefulness of any information, apparatus, product, or process disclosed, or represents that its use would not infringe privately owned rights. Reference herein to any specific commercial product, process, or service by trade name, trademark, manufacturer, or otherwise does not necessarily constitute or imply its endorsement, recommendation, or favoring by the United States Government or any agency thereof. The views and opinions of authors expressed herein do not necessarily state or reflect those of the United States Government or any agency thereof.

This report has been reproduced directly from the best available copy.

Available to DOE and DOE contractors from the Office of Scientific and Technical Information, P.O. Box 62, Oak Ridge, TN 37831; prices available from (615) 576-8401.

Available to the public from the National Technical Information Service, U.S. Department of Commerce, 5285 Port Royal Road, Springfield, VA 22161. 


\section{DISCLAIMER}

Portions of this document may be illegible in electronic image products. Images are produced from the best available original document. 
WSRC-RP-98-01051, Rev. 0

Keywords: Cyrstalline silicotitanate, CST, Equilibrium curves, Isotherms

Retention: Permanent

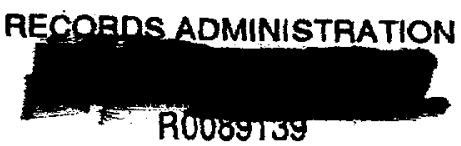

\section{Powdered Crystalline Silicotitanate (CST) Isotherms for SRS Wastes (U)}

R. A. Jacobs

Publication Date: September 11, 1998

Westinghouse Savannah River Company

Savannah River Technology Center

A iken, SC 29808

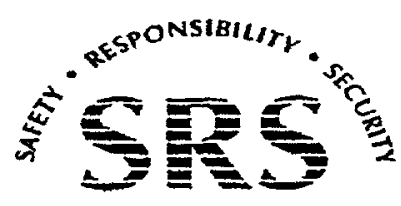

SAVANNAH RIVER SITE 
WSRC-RP-98-01051

Page 2 of 11

\section{APPROVALS}

\section{Author}

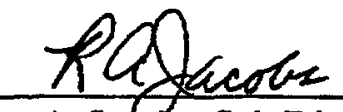

R. A. Jacobs, Salt Disposition Flowsheet Team

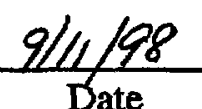

\section{Design Check}

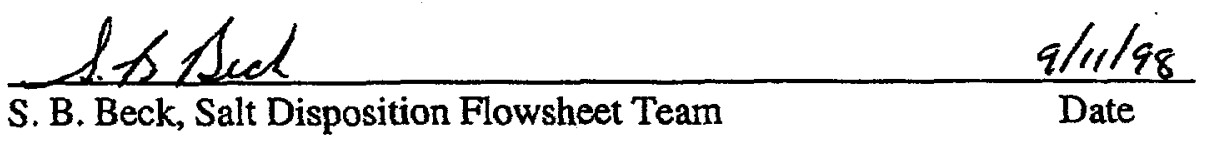

\section{Approvals}

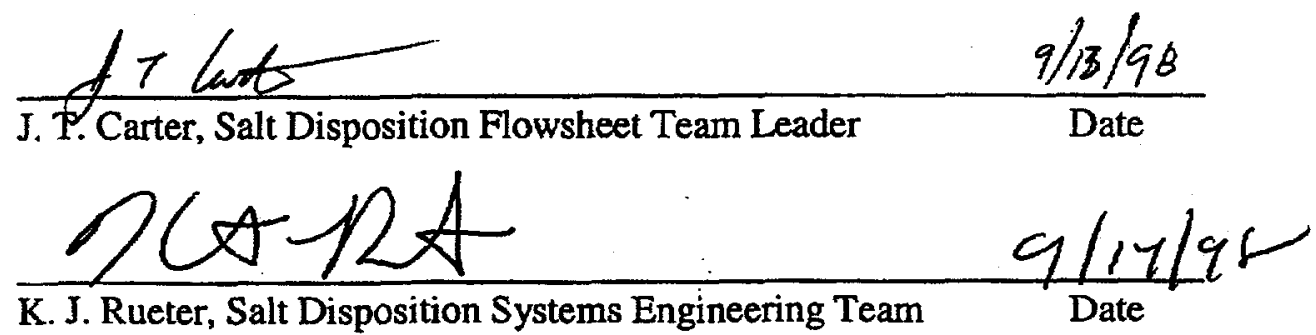




\section{Crystalline Silicotitanate (CST) \\ Isotherms for SRS Wastes (U)}

\section{SUMMARY}

One of the primary inputs for modeling an ion exchange column is the equilibrium driving force for mass transfer between the solution and the solid phase. The equilibrium relationship is typically known as an isotherm. This document contains the predicted isotherms for the various Savannah River Site (SRS) waste types in equilibrium with powdered (ungranulated) crystalline silicotitanate (CST). Six isotherms for SRS waste are included: One for each of the three waste types (average, high hydroxide, and high nitrate) and one for each waste type at bounding potassium and cesium. The predictions were made using a proprietary computer program titled CST Ion Exchange Version 5 (CSTIEX5).[1]

\section{WASTE COMPOSITION}

A part of modeling an ion exchange column involves evaluating the impact of variations in waste composition. SRS salt waste fall into three categories: average, high hydroxide, and high nitrate. The compositions used for this study are based on Table 5.1-4 of the Salt Team Assumptions and Bases document [2] and are shown in Table 1.

Table 1

SRS WASTE COMPOSITIONS

\begin{tabular}{|c|c|c|c|}
\hline Component & $\begin{array}{l}\text { A verage } \\
\text { (M) }\end{array}$ & $\begin{array}{l}\text { High OH' } \\
\text { (NI) }\end{array}$ & $\begin{array}{l}\mathrm{High} \mathrm{NO}_{3}^{\circ} \\
\text { (M) }\end{array}$ \\
\hline $\mathrm{Na}^{+}$ & 5.6 & 5.6 & 5.6 \\
\hline $\mathrm{Cs}^{+}$ & 0.00014 & 0.00037 & 0.00014 \\
\hline $\mathrm{K}^{+}$ & 0.015 & 0.030 & 0.0041 \\
\hline $\mathrm{OH}^{-}$ & 1.91 & 3.05 & 1.17 \\
\hline $\mathrm{NO}_{3}^{\circ}$ & 2.14 & 1.10 & 2.84 \\
\hline $\mathrm{NO}_{2}^{-}$ & 0.52 & 0.74 & 0.37 \\
\hline $\mathrm{AlO}_{2}$ & 0.31 & 0.27 & 0.32 \\
\hline $\mathrm{CO}_{3}{ }^{2-}$ & 0.16 & 0.17 & 0.16 \\
\hline $\mathrm{SO}_{4}{ }^{2-}$ & 0.15 & 0.030 & 0.22 \\
\hline $\mathrm{Cl}^{-}$ & 0.025 & 0.010 & 0.040 \\
\hline $\bar{F}$ & 0.032 & 0.010 & 0.050 \\
\hline $\mathrm{PO}_{4}{ }^{3-}$ & 0.010 & 0.008 & 0.010 \\
\hline $\mathrm{C}_{2} \mathrm{O}_{4}^{2}$ & 0.008 & 0.008 & 0.008 \\
\hline $\mathrm{SiO}_{3}^{2-}$ & 0.004 & 0.004 & 0.004 \\
\hline $\mathrm{MoO}_{4}{ }^{2-}$ & 0.0002 & 0.0002 & 0.0002 \\
\hline
\end{tabular}

These compositions represent the typical values for the three SRS waste types. They represent the extremes of the major components, e.g., hydroxide, nitrite, nitrate. However, they may not be the "worst case" compositions that can be encountered. A comparison of waste compositions and predicted isotherms for wastes from other sites (e.g., Hanford, Oak Ridge) reveals there are two other cations frequently present in other wastes which are low in the three waste types. They are potassium and strontium. High levels of these two cations $\left(0.415 \mathrm{M} \mathrm{K}^{+}\right.$and $\left.4.5 \mathrm{E}-04 \mathrm{M} \mathrm{Sr}^{++}\right)$result in an isotherm that has a predicted solid/solution equilibrium ratio almost an order of magnitude lower than for SRS waste. Because of its high $\mathrm{pH}, \mathrm{SRS}$ waste has very little soluble $\mathrm{Sr}$ - and that which is present is removed by treatment with monosodium titanate (MST). 
Therefore, it is important to examine the impact of a bounding potassium concentration. Estimates of blended salt solution feeds to an ion exchange system are not available to support preliminary column siting activities performed by SRS engineering and outside consultants. Instead, historical analysis of salt solution supernates was examined to provide a bounding potassium value. ${ }^{1}[3,4]$ The data are shown in Table 2.

Table 2

\section{SUPERNATE POTASSIUM CONCENTRATIONS}

\begin{tabular}{|c|c|c|c|}
\hline Tank & $\begin{array}{c}\mathrm{K}^{+} \\
(\mathrm{M})\end{array}$ & $\begin{array}{l}\mathrm{Fa}^{+} \\
(\mathrm{NI})\end{array}$ & $\begin{array}{l}\mathrm{K}^{+} \text {Adjusted } \\
\text { to } 5.6 \mathrm{MI} \mathrm{Na}^{+} \\
\text {(MI) }\end{array}$ \\
\hline $7 \mathrm{~F}$ & 0.033 & 5.8 & 0.032 \\
\hline $10 \mathrm{H}$ & 0.013 & 9.2 & 0.008 \\
\hline 17 F Batch 3 & 0.053 & 6.9 & 0.043 \\
\hline 6 (6) & Of & & $\sqrt{6164}$ \\
\hline Batch 5 & 0.036 & 7.5 & 0.027 \\
\hline $20 \mathrm{~F}$ & 0.023 & 7.7 & 0.017 \\
\hline $29 \mathrm{H}$ & 0.078 & 10.9 & 0.040 \\
\hline $30 \mathrm{H}$ & 0.078 & 13.3 & 0.033 \\
\hline$\overline{41 \mathrm{H}}$ & 0.041 & 5.0 & 0.046 \\
\hline $43 \mathrm{H}$ & 0.018 & 5.8 & 0.017 \\
\hline $44 \mathrm{H}$ & 0.071 & 10.6 & 0.038 \\
\hline $24[3]$ & 0.0068 & 5.8 & 0.007 \\
\hline $25[4]$ & 0.17 & 13.8 & 0.069 \\
\hline $26[4]$ & 0.18 & 16.7 & 0.060 \\
\hline $27[4]$ & 0.14 & 12.1 & 0.065 \\
\hline $28[4]$ & 0.13 & 13.2 & 0.055 \\
\hline 29 [4] & 0.086 & 14.0 & 0.034 \\
\hline $30[4]$ & 0.039 & 9.1 & 0.024 \\
\hline 32 [4] & 0.019 & 5.3 & 0.020 \\
\hline $38[4]$ & 0.083 & 19.1 & 0.024 \\
\hline $43[4]$ & 0.085 & 14.4 & 0.033 \\
\hline
\end{tabular}

Based on this data, a bounding value of $0.15 \mathrm{M} \mathrm{K}^{+}$was chosen for the purposes of this evaluation.

One other cation is very important - that is the bounding value of $\mathrm{Cs}$ itself. This is because the equilibrium ratio between the $\mathrm{Cs}$ on the resin and $\mathrm{Cs}$ in solution decreases as the [Cs] increases. Therefore, isotherms need to bound the starting $\mathrm{Cs}$ concentration. For this study, the highest value of $\mathrm{Cs}$ for each waste is $\approx 28 \mathrm{Ci} / \mathrm{gal}{ }^{2}$

\section{RESULTS}

The model requires the input of the principal cations and anions. These include the ions that comprise the bulk of the ionic strength as well as those which compete for sites on the CST. The inputs to the model

\footnotetext{
'Some of the data in Table 2, provided by D. D. Walker, is not contained in references 3 and 4. The values in Table 2 are used in lieu of projected compositions to be developed from the Tank Farm database and the waste removal schedule. When the projected values are available, the isotherms will be re-developed if necessary to provide bounding estimates.

${ }^{2}$ Based on 22.5 atom percent ${ }^{137} \mathrm{Cs}$.
} 
are shown in each input table. The additional inputs are the same for each run:

$$
\begin{aligned}
& \text { Temperature }=298.15 \mathrm{~K} \\
& \text { Material }=\mathrm{Na} \text { form } \\
& \text { Liquid }=0.100 \mathrm{~L} \\
& \text { Solid }=0.050 \mathrm{~g} \\
& \text { Density }=1258 \mathrm{~kg} / \mathrm{m}^{3}
\end{aligned}
$$

The model simulates the results of an experiment to determine the distribution coefficient $\left(K_{d}\right)$. In a $K_{d}$ experiment, a quantity of solution is placed in contact with a quantity of ion exchange material. After reaching equilibrium, the concentrations of various cations (in the case of a cation resin) are measured. The ending solution concentrations for each cation are used to calculate the $\mathrm{K}_{\mathrm{d}}$ for that cation, the loading on the resin, and the equilibrium ratio between the ending solution concentration and the resin. A series of final solution concentrations versus resin concentrations define the equilibrium curve or isotherm. The model predictions of equilibrium solution and solid concentrations are shown for each waste type in each result table as $\mathrm{C}$ (the ending concentration of $\mathrm{Cs}$ in solution in $\mathrm{mmol} \mathrm{Cs} / \mathrm{L}$ solution) and $\mathrm{Q}$ (the ending concentration of Cs on the CST in mmol Cs/g CST). Figure 1 is plot of the results for all six waste types. Samples of the input and output files are in Appendix A.

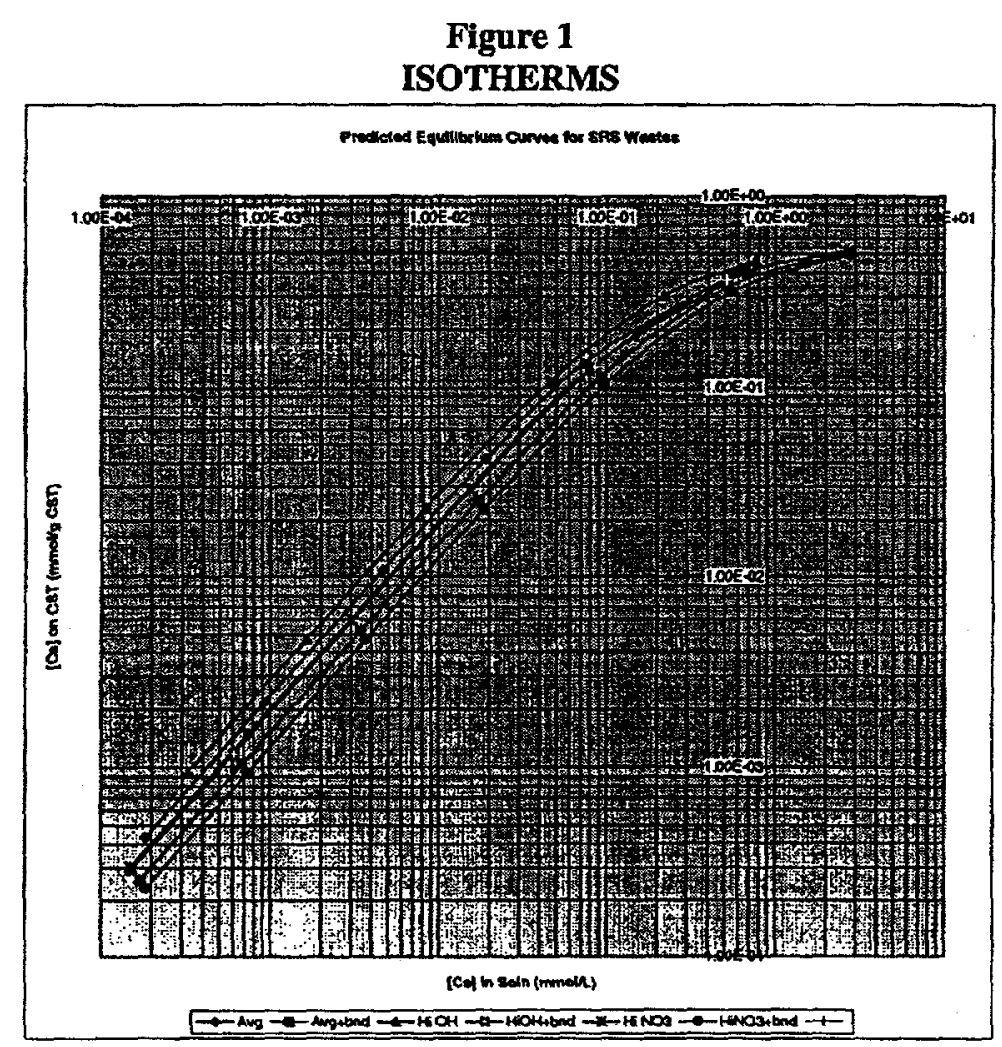

General comments regarding the model runs:

1) In the bounding wastes, the increase in potassium is offset by decreasing the sodium to maintain a constant ionic strength. 
2) In each case, one of the ions is increased to force the ionic balance. This is noted by the nominal + the increment. For example, in the nominal SRS average salt waste, the hydroxide is increased by $0.00414 \mathrm{M}$ as noted; that is, $1.91+0.00414$.

3) In all SRS cases, the molybdate was excluded and the ionic strengths due to silicate and oxalate were included with the nitrate ion.

Average SRS Salt Waste

Table 3

INPUT

\begin{tabular}{|c|c|c|}
\hline Conum & $\begin{array}{l}\text { Nomintul } \\
\text { (MI) }\end{array}$ & $\begin{array}{c}\text { Boundling } \\
\text { (II) }\end{array}$ \\
\hline $\mathrm{Na}^{+}$ & 5.6 & 5.465 \\
\hline $\mathrm{Cs}^{+}$ & $1.4 \mathrm{E}-04$ & $7.0 \mathrm{E}-04$ \\
\hline $\mathrm{H}^{+}$ & $5.24 \mathrm{E}-15$ & $5.24 \mathrm{E}-15$ \\
\hline $\mathrm{K}^{+}$ & 0.015 & 0.150 \\
\hline OH & $1.91+0.00414$ & $1.91+0.00470$ \\
\hline $\mathrm{NO}_{3}^{-}$ & $2.164^{*}$ & $2.164^{*}$ \\
\hline $\mathrm{NO}_{2}^{\circ}$ & 0.52 & 0.52 \\
\hline $\mathrm{Al}(\mathrm{OH})_{4}^{-}$ & 0.31 & 0.31 \\
\hline $\mathrm{CO}_{3}{ }^{2}$ & 0.16 & 0.16 \\
\hline $\mathrm{SO}_{4}=$ & 0.15 & 0.15 \\
\hline $\mathrm{Cl}^{\circ}$ & 0.025 & 0.025 \\
\hline $\bar{F}$ & 0.032 & 0.032 \\
\hline $\mathrm{PO}_{4}^{-3}$ & 0.010 & 0.010 \\
\hline
\end{tabular}

Table 4

RESULTS

\begin{tabular}{|c|c|c|c|}
\hline \multicolumn{2}{|c|}{ Nominal } & \multicolumn{2}{|c|}{ Bounding } \\
\hline$\frac{\mathrm{C}}{(\mathrm{mmol} \mathrm{Cs} / \mathrm{L})}$ & (mmol (s/g CST) & $\begin{array}{c}\text { C } \\
\text { (mumul } \mathrm{Cs} / \mathrm{L})\end{array}$ & $($ (mmol $\mathrm{Cs} / \mathrm{g}$ CST) \\
\hline 6.31E-01 & 4.19E-01 & 2.75 & $5.10 \mathrm{E}-01$ \\
\hline $7.30 \mathrm{E}-02$ & $1.34 \mathrm{E}-01$ & $5.31 \mathrm{E}-01$ & $3.38 \mathrm{E}-01$ \\
\hline $1.90 \mathrm{E}-02$ & $4.20 \mathrm{E}-02$ & $9.29 \mathrm{E}-02$ & $1.14 \mathrm{E}-01$ \\
\hline $4.61 \mathrm{E}-03$ & $1.08 \mathrm{E}-02$ & $1.73 \mathrm{E}-02$ & $2.54 \mathrm{E}-02$ \\
\hline $9.14 \mathrm{E}-04$ & $2.17 \mathrm{E}-03$ & $3.41 \mathrm{E}-03$ & $5.18 \mathrm{E}-03$ \\
\hline $1.82 \mathrm{E}-04$ & $4.35 \mathrm{E}-04$ & $6.80 \mathrm{E}-04$ & $1.04 \mathrm{E}-03$ \\
\hline $3.65 \mathrm{E}-05$ & $8.71 \mathrm{E}-05$ & $1.70 \mathrm{E}-04$ & $2.60 \mathrm{E}-04$ \\
\hline $9.12 \mathrm{E}-06$ & $2.18 \mathrm{E}-05$ & $3.40 \mathrm{E}-05$ & $5.20 \mathrm{E}-05$ \\
\hline $1.82 \mathrm{E}-06$ & $4.35 E-06$ & $6.80 \mathrm{E}-06$ & $1.04 \mathrm{E}-05$ \\
\hline
\end{tabular}


Table 5

INPUT

\begin{tabular}{|c|c|c|}
\hline Component & $\begin{array}{c}\text { Nominal } \\
\text { (1) }\end{array}$ & $\begin{array}{l}\text { Bounding } \\
\text { (MI) }\end{array}$ \\
\hline $\mathrm{Na}^{+}$ & 5.6 & 5.48 \\
\hline $\mathrm{Cs}^{+}$ & $3.7 \mathrm{E}-04$ & $7.0 \mathrm{E}-04$ \\
\hline $\mathrm{H}^{+}$ & $3.25 \mathrm{E}-15$ & $3.25 \mathrm{E}-15$ \\
\hline $\mathrm{K}^{+}$ & 0.030 & 0.150 \\
\hline $\mathrm{OH}$ & $3.05+0.00237$ & $3.05+.00270$ \\
\hline $\mathrm{NO}_{3}^{-}$ & 1.124 & 1.124 \\
\hline $\mathrm{NO}_{2}^{-}$ & 0.74 & 0.74 \\
\hline $\mathrm{Al}(\mathrm{OH})_{4}^{-}$ & 0.27 & 0.27 \\
\hline $\mathrm{CO}_{3}{ }^{2}$ & 0.17 & 0.17 \\
\hline $\mathrm{SO}_{4}{ }^{2}$ & 0.030 & 0.030 \\
\hline $\mathrm{Cl}^{\circ}$ & 0.010 & 0.010 \\
\hline$F$ & 0.010 & 0.010 \\
\hline $\mathrm{PO}_{4}^{-3}$ & 0.008 & 0.008 \\
\hline
\end{tabular}

Table 6

RESULTS

\begin{tabular}{|c|c|c|c|}
\hline \multicolumn{2}{|c|}{ Nomimal } & \multicolumn{2}{c|}{ Bounding } \\
\hline $\begin{array}{c}\mathrm{C} \\
(\mathrm{mmol} \mathrm{Cs} / \mathrm{L})\end{array}$ & $\begin{array}{c}\mathrm{Q} \\
(\mathrm{mm}) \mathrm{Cs} / \mathrm{g} \mathrm{CST})\end{array}$ & $\begin{array}{c}\mathrm{C} \\
(\mathrm{mmol} \mathrm{Cs} / \mathrm{L})\end{array}$ & $\begin{array}{c}\mathrm{Q} \\
(\mathrm{mmol} \mathrm{Cs} / \mathrm{g} \\
\mathrm{CST})\end{array}$ \\
\hline $7.70 \mathrm{E}-01$ & $4.60 \mathrm{E}-01$ & 2.74 & $5.23 \mathrm{E}-01$ \\
\hline $2.19 \mathrm{E}-01$ & $3.03 \mathrm{E}-01$ & $5.16 \mathrm{E}-01$ & $3.68 \mathrm{E}-01$ \\
\hline $4.60 \mathrm{E}-02$ & $1.08 \mathrm{E}-01$ & $8.53 \mathrm{E}-02$ & $1.29 \mathrm{E}-01$ \\
\hline $8.38 \mathrm{E}-03$ & $2.32 \mathrm{E}-02$ & $1.56 \mathrm{E}-02$ & $2.89 \mathrm{E}-02$ \\
\hline $1.64 \mathrm{E}-03$ & $4.71 \mathrm{E}-03$ & $3.05 \mathrm{E}-03$ & $5.90 \mathrm{E}-03$ \\
\hline $3.27 \mathrm{E}-04$ & $9.45 \mathrm{E}-04$ & $6.08 \mathrm{E}-04$ & $1.18 \mathrm{E}-03$ \\
\hline $8.18 \mathrm{E}-05$ & $2.36 \mathrm{E}-04$ & $1.52 \mathrm{E}-04$ & $2.96 \mathrm{E}-04$ \\
\hline $1.64 \mathrm{E}-05$ & $4.73 \mathrm{E}-05$ & $3.04 \mathrm{E}-05$ & $5.93 \mathrm{E}-05$ \\
\hline $4.09 \mathrm{E}-06$ & $1.18 \mathrm{E}-05$ & $7.59 \mathrm{E}-06$ & $1.48 \mathrm{E}-05$ \\
\hline
\end{tabular}


WSRC-RP-98-01051

Page 8 of 11

High Nitrate SRS Waste

Table 7

INPUT

\begin{tabular}{|c|c|c|}
\hline Component & $\begin{array}{c}\text { Nominal } \\
\text { (MI) }\end{array}$ & $\begin{array}{l}\text { Bounding } \\
\text { (AI) }\end{array}$ \\
\hline $\mathrm{Na}^{+}$ & 5.6 & 5.4541 \\
\hline $\mathrm{Cs}^{+}$ & $1.4 \mathrm{E}-04$ & $7.0 \mathrm{E}-04$ \\
\hline $\mathrm{H}^{+}$ & $8.55 \mathrm{E}-15$ & $5.24 \mathrm{E}-15$ \\
\hline $\mathrm{K}^{+}$ & 0.0041 & 0.150 \\
\hline $\mathrm{OH}$ & $1.17+0.00024$ & $1.17+0.00080$ \\
\hline $\mathrm{NO}_{3}^{-}$ & 2.864 & 2.864 \\
\hline $\mathrm{NO}_{2}^{-}$ & 0.37 & 0.37 \\
\hline $\mathrm{Al}(\mathrm{OH})_{4}^{-}$ & 0.32 & 0.32 \\
\hline $\mathrm{CO}_{3}{ }^{=}$ & 0.16 & 0.16 \\
\hline $\mathrm{SO}_{4}{ }^{2}$ & 0.22 & 0.22 \\
\hline $\mathrm{Cl}^{-}$ & 0.040 & 0.040 \\
\hline$F$ & 0.050 & 0.050 \\
\hline $\mathrm{PO}_{4}^{-3}$ & 0.010 & 0.010 \\
\hline
\end{tabular}

Table 8

RESULTS

\begin{tabular}{|c|c|c|c|}
\hline \multicolumn{2}{|c|}{ Nominal } & \multicolumn{2}{|c|}{ Bounding } \\
\hline $\begin{array}{c}\mathrm{C} \\
(\mathrm{nmmol} \operatorname{Cs} / \mathrm{L})\end{array}$ & $\frac{\mathrm{Q}}{(\mathrm{mm} m \mathrm{Cs} / \mathrm{g} \mathrm{CST})}$ & $\begin{array}{c}\mathrm{C} \\
\text { (Imino) } \\
\text { Cs/L) }\end{array}$ & $\begin{array}{c}\mathrm{Q} \\
\text { (mmol Csig CST) }\end{array}$ \\
\hline $6.39 \mathrm{E}-01$ & $4.01 \mathrm{E}-01$ & 2.75 & $4.98 \mathrm{E}-01$ \\
\hline $7.78 \mathrm{E}-02$ & $1.24 \mathrm{E}-01$ & $5.42 \mathrm{E}-01$ & $3.16 \mathrm{E}-01$ \\
\hline $1.53 \mathrm{E}-02$ & $2.95 \mathrm{E}-02$ & $9.82 \mathrm{E}-02$ & $1.04 \mathrm{E}-01$ \\
\hline $2.99 \mathrm{E}-03$ & $6.02 \mathrm{E}-03$ & $1.86 \mathrm{E}-02$ & $2.29 \mathrm{E}-02$ \\
\hline $7.44 \mathrm{E}-04$ & $1.51 \mathrm{E}-03$ & $3.66 \mathrm{E}-03$ & $4.67 \mathrm{E}-03$ \\
\hline $1.49 \mathrm{E}-04$ & $3.03 \mathrm{E}-04$ & $7.31 \mathrm{E}-04$ & $9.38 \mathrm{E}-04$ \\
\hline $2.97 \mathrm{E}-05$ & $6.05 \mathrm{E}-05$ & $1.83 \mathrm{E}-04$ & $2.35 \mathrm{E}-04$ \\
\hline $4.96 \mathrm{E}-06$ & $1.01 \mathrm{E}-05$ & $3.65 \mathrm{E}-05$ & $4.69 \mathrm{E}-05$ \\
\hline & & $7.31 \mathrm{E}-06$ & $9.39 \mathrm{E}-06$ \\
\hline
\end{tabular}




\section{REFERENCES}

1. Rayford G. Anthony and Zhixin Zheng, CST Ion Exchange Version 5 (CSTIXE5), Department of Chemical Engineering, Texas A\&M University, College Station.

2. P. L. Rutland, et al, Bases, Assumptions, and Results of the Flowsheet Calculations for the Initial Eighteen Salt Disposition Alternatives (U), WSRC-RP-98-00166, June 15, 1998.

3. J. R. Fowler and L. M. Lee, Projected Composition of Decontaminated Salt from Tank 24, DPST-82404, March 1982.

4. D. D. Walker, et al., Composition of Tank Farm Supernate Samples (U), WSRC-RP-93-1009, July 1993. 


\section{APPENDIX A}

\section{CSTIEX5 input file}

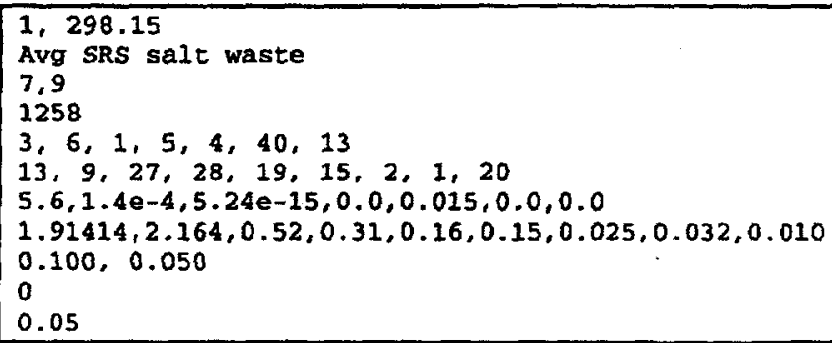

\section{CSTIEXS output file}

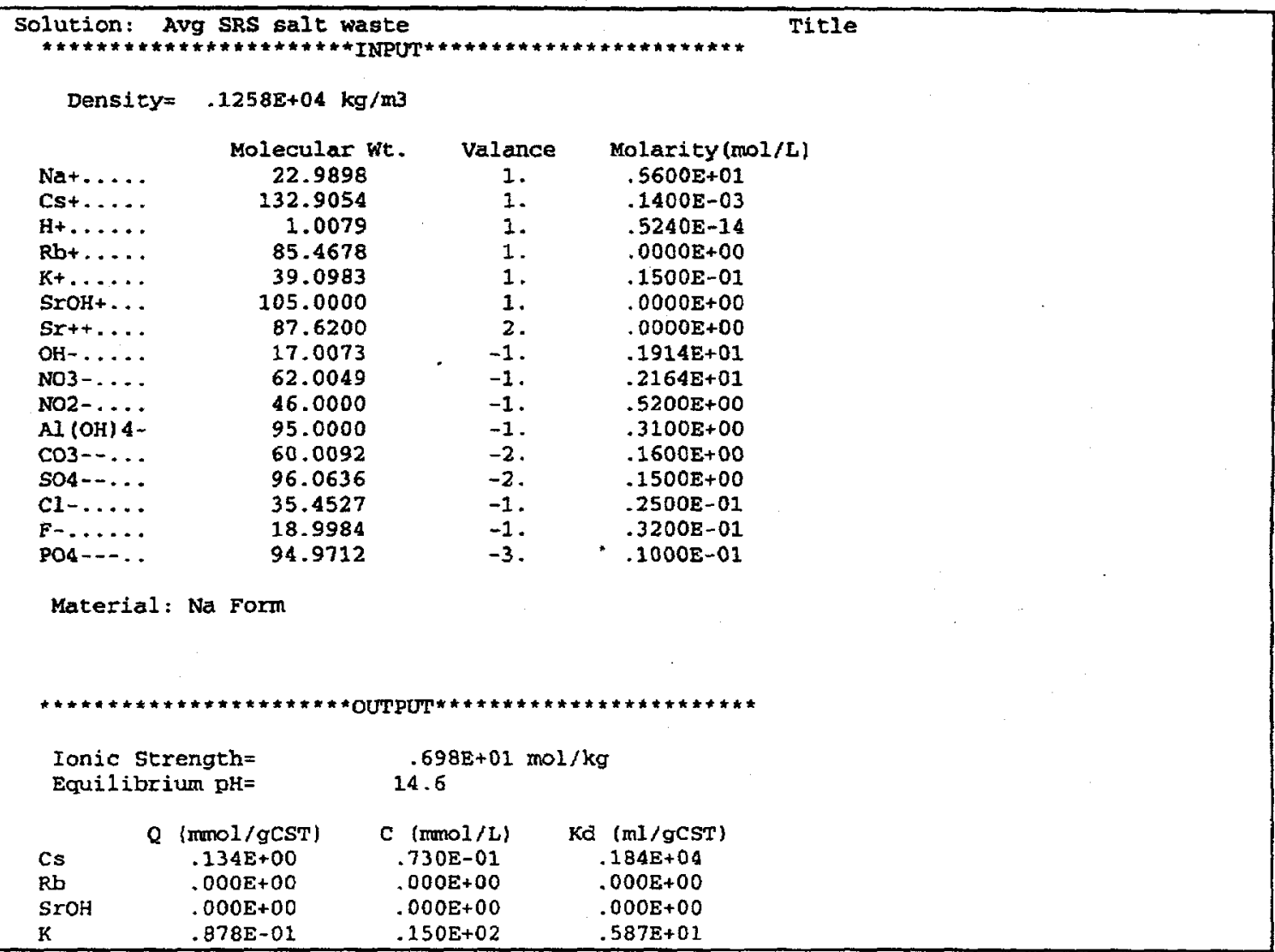




\section{DISTRIBUTTION}

W. L. Tamosaitis, 773-A

S. A. Fink, 773-A

D. D. Walker, 773-A

D. J. McCabe, 773-43A

W. D. King, 773-41A

E. W. Holtzscheiter, 773-A

C. T. Randall, 704-T

S. F. Piccolo, 704-3N

K. J. Reuter, 704-3N

J. T. Carter, 704-3N

L. M. Papouchado, 704-3N

P. I. Hudson, 704-3N

G. E. Abell, 704-3N

J. L. Barnes, 704-3N

E. T. Murphy, 704-3N

E. J. Kosiancic, 704-3N

E. Cussler, 704-3N

J. Watson, 704-3N

R. A. Jacobs, 704-196N

S. B. Beck, 704-196N

J. R. Fowler, 704-196N

J. A. Amari, 704-3N

J. T. Case

O. E. Duarte, $704-196 \mathrm{~N}$ 